\title{
Effects of dietary n -6: n -3 PUFA ratio on the growth performance, serum lipid and adipokine profiles, tissue fatty acid composition and gene expression of lipid metabolism of finishing pigs
}

Jing Chen

Shenyang Agricultural University

Jiantao Li

Shenyang Agricultural University

Xianjun Liu ( $D$ lchenj@163.com )

Shenyang Agricultural University https://orcid.org/0000-0002-5790-6503

Hongze Cui

Shenyang Agricultural University

Liyan Wang

Shenyang Agricultural University

Jiaxing Zheng

Shenyang Agricultural University

Xin Li

Shenyang Agricultural University

Research

Keywords: n-6:n-3 PUFA ratios, Lipid metabolism, Inflammation, Gene expression, Finishing pigs

Posted Date: December 15th, 2020

DOI: https://doi.org/10.21203/rs.3.rs-127949/v1

License: (c) (1) This work is licensed under a Creative Commons Attribution 4.0 International License.

Read Full License 


\section{Abstract \\ Background}

The health benefits of n-3 polyunsaturated fatty acids (PUFA), such as cardioprotective, anti-inflammatory and hypo-triglyceridemic properties, have been well documented. However, current dietary modification can easily lead to excessive concentrations of n-6 PUFA and an imbalance in the n-6:n-3 PUFA ratio, resulting in the pathogenesis of obesity and related diseases. This study investigated the effects of various dietary n-6:n-3 PUFA ratios on the growth performance, blood lipid and cytokine profiles, tissue fatty acid composition, and gene expression involved in lipid metabolism in finishing pigs. Seventy-two crossbred [(Duroc $\times$ Landrace $) \times$ Yorkshire] finishing pigs $(68.5 \pm 1 \cdot 8 \mathrm{~kg})$ were fed one of four isoenergetic diets with n-6:n-3 PUFA ratios of 2:1, 3:1, 5:1 and 8:1.

\section{Results}

Pigs fed diets with n-6:n-3 PUFA ratios of 3:1 and 5:1 had a higher average daily gain (ADG) and average daily feed intake (ADFI) $(P<0.05)$ and a lower feed conversion ratio (FCR) $(P<0.05)$. The concentrations of triglyceride (TG) and total cholesterol (TC) of pigs fed diets with n-6:n-3 PUFA ratios of 1:1 to $5: 1$ decreased $(P<0.05)$, whereas the ratio of concentrations of high-density to low-density lipoprotein cholesterol (HDL-C:LDL-C) in pigs fed a diet with an n-6:n-3 PUFA ratio of 2:1 increased $(P<0.05)$ compared with those fed a diet with an n-6:n-3 PUFA ratio of 8:1. Pigs fed a diet with n-6:n-3 PUFA ratios of 2:1 and 3:1 had lower concentrations of leptin (LEP) and interleukin 6 (IL-6) $(P<0.05)$, and higher concentrations of adiponectin (APN) $(P<0.05)$ than those fed diets with n-6:n-3 PUFA ratios of 5:1 and 8:1. Diets with n-6:n-3 PUFA ratios of 2:1 and 3:1 markedly down-regulated the expression levels of peroxisome proliferator-activated receptor-y (PPARY) and lipoprotein lipase (LPL) in both the longissimus dorsi muscle (LM) and subcutaneous adipose tissue (SCAT), but up-regulated the expression level of adipocyte fatty acid binding protein (aP2) in the LM. The expression levels of aP2 and hormone- sensitive lipase were similar to those of PPARY in the SCAT.

\section{Conclusions}

This study demonstrated that dietary n-6:n-3 PUFA ratios between 3:1 and 5:1 beneficially affected growth performance, optimize blood lipid and adipocytokine levels, enhanced absorption and deposition of n-3 PUFA and regulated lipid metabolism-related genes.

\section{Background}

Lipids are key macronutrients in the human and animal diet which can provide energy to improve the energy status and modify the fatty acids (FA) composition of animal tissues. The type and proportion of dietary FA consumed affect human health and whole-body physiology [1]. Studies have shown that 
consuming polyunsaturated fatty acids (PUFA) offer health benefits and could reduce the risk of coronary heart disease compared with saturated fatty acids (SFA) [2]. Based on their chemical structures, PUFA are classified into two series: $n-6$ and n-3 PUFA. The essential FA, C18:2n-6 and C18:3n-3, cannot be synthesized de novo, and so must be obtained from dietary sources. Those two FA are incorporated directly into tissue lipids or converted into their derivative n-6 or n-3 long-chain PUFA, respectively, such as arachidonic acid (ALA, C20:4n-6), eicosapentaenoic acid (EPA, C20:5n-3) or docosahexaenoic acid (DHA, C22n-3).

Several sources of fat can provide PUFA: fish oil and some vegetable oils, such as linseed and perilla oils, tend to contain higher proportions of n-3 PUFA while other sources tend to contain higher proportions of n-6 PUFA, such as corn and soybean oils. Several types of feedstuff used in commercial swine diets such as corn and soybean meal contain higher proportions of $n-6$ PUFA. Therefore, dietary modification can easily lead to an imbalance in the n-6:n-3 PUFA ratio: an increase in n-6 PUFA alongside a marked reduction in n-3 PUFA can result in a high n-6:n-3 PUFA ratio [3]. Although n-3 PUFA have been demonstrated to provide many health benefits, such as cardioprotective, anti-inflammatory and hypotriglyceridemic properties, there is concern regarding the possibly adverse effects from excessive n-3 PUFA in the diet, because their high degree of unsaturation may increase oxidative stress and lipid peroxidation. For example, EPA and DHA have a greater number of unsaturated bonds than ALA, which make them more susceptible to oxidation [4]. On the other hand, from a functional aspect, n-6 and n-3 PUFA interact with each other in biological functions and coordinate to regulate biological processes, which may play a role in the pathogenesis of obesity and related diseases. Therefore, nutritionists have tended to focus more on the effects of the n-6:n-3 PUFA ratio rather than the content of a particular PUFA $[5,6]$.

Previous studies have shown that the n-6:n-3 PUFA ratio plays a key role in regulating lipid metabolism and inflammation in finishing pigs $[7,8]$. The objective of the present study is to extend knowledge from previous studies by evaluating the effects of adding sources of oil to the diet containing different n-6:n-3 PUFA ratios on the growth performance, blood lipid and adipocytokine levels, tissue FA composition and gene expressions of finishing pigs to propose a possible mechanism of how the n-6:n-3 PUFA ratio regulates lipid metabolism.

\section{Methods}

\section{Animals experimentation}

A total of 72 crossbred [(Duroc $\times$ Landrace) $\times$ Yorkshire] pigs with an average initial weight of $68.54 \pm$ $1.80 \mathrm{~kg}$ were assigned to four groups in a completely randomized design. Each group consisted of six replicate pens ( 3 pens of barrows and 3 pens of gilts) with three pigs per pen. The pigs in the four groups were fed isoenergetic diets ( $2 \%$ fat), prepared using $1.6 \%, 0.8 \%, 0.4 \%$ and $0 \%$ of linseed oil to replace equivalent amounts of soybean oil so that the dietary n-6:n-3 PUFA ratios of the four diets were about 2:1, 3:1, 5:1 and 8:1, respectively. The diets were formulated to meet or exceed the NRC (2012) nutrient 
requirements. The soybean and linseed oils used in the experiment were obtained from Jiuzhou Dadi Biotechnology Company (Liaoning Province, China). The pigs received feed and water ad libitum in individual crates on concrete flooring. The experiment lasted for $45 \mathrm{~d}$. The composition and nutrient levels of the four diets are presented in Table 1 and the dietary FA composition in Table 2. 
Composition and analysis of experimental diets ( $\mathrm{g} / \mathrm{kg}$; air-dry basis)

\begin{tabular}{|c|c|c|c|c|}
\hline \multirow[t]{2}{*}{ Diet } & \multicolumn{4}{|c|}{ n-6:n-3 PUFA ratio ${ }^{1}$} \\
\hline & $2: 1$ & $3: 1$ & $5: 1$ & $8: 1$ \\
\hline \multicolumn{5}{|l|}{ Ingredients } \\
\hline Corn & 67.00 & 67.00 & 67.00 & 67.00 \\
\hline Distillers dried grains with solubles & 4.00 & 4.00 & 4.00 & 4.00 \\
\hline Corn germ meal & 2.00 & 2.00 & 2.00 & 2.00 \\
\hline Soybean meal (47.5\% Pr) & 19.00 & 19.00 & 19.00 & 19.00 \\
\hline Wheat bran & 3.00 & 3.00 & 3.00 & 3.00 \\
\hline Limestone & 1.00 & 1.00 & 1.00 & 1.00 \\
\hline Dicalcium phosphate & 0.70 & 0.70 & 0.70 & 0.70 \\
\hline Salt & 0.30 & 0.30 & 0.30 & 0.30 \\
\hline Soybean oil & 0.40 & 1.20 & 1.60 & 2.00 \\
\hline Linseed oil & 1.60 & 0.80 & 0.40 & 0.00 \\
\hline Premix $^{2}$ & 1.00 & 1.00 & 1.00 & 1.00 \\
\hline \multicolumn{5}{|l|}{ Nutrient level } \\
\hline Digestible energy (MJ/kg) & 14.07 & 14.07 & 14.07 & 14.07 \\
\hline Crude protein $\mathrm{CP}$ & 15.80 & 15.80 & 15.80 & 15.80 \\
\hline Crude lipid EE & 5.04 & 5.04 & 5.04 & 5.04 \\
\hline Crude fiber CF & 3.24 & 3.24 & 3.24 & 3.24 \\
\hline Ash & 3.94 & 3.94 & 3.94 & 3.94 \\
\hline $\mathrm{Ca}$ & 0.60 & 0.60 & 0.60 & 0.60 \\
\hline
\end{tabular}

${ }^{1}$ To replace equivalent amounts of soybean oil, $1.6,0.8,0.4$ and $0.0 \%$ of linseed oil were used, making the dietary n-6:n-3 PUFA ratios about 2:1, 3:1,5:1 and 8:1, respectively

2Premix provided per kg diet: 8,000 IU of vitamin $A$ as retinol acetate; $15 \mathrm{mg}$ of vitamin $\mathrm{B}_{1}$ as thiamin; $30 \mathrm{mg}$ of vitamin $B_{2}$ as riboflavin; $15 \mathrm{mg}$ of vitamin $B_{6}$ as pyridoxine; $0.5 \mathrm{mg}$ of vitamin $B_{12}$ as cobalamin; 3000 IU of vitamin $\mathrm{D}_{3}$ as cholecalciferol; $60 \mathrm{IU}$ of vitamin $\mathrm{E}$ as DL-a-tocopherol acetate; $35 \mathrm{mg}$ vitamin $\mathrm{K}$ as menadione; $175 \mathrm{mg}$ of nicotinic acid; $50 \mathrm{mg}$ of pantothenic acid; $2.5 \mathrm{mg}$ of biotin; $5 \mathrm{mg}$ of folic acid; $3 \mathrm{mg}$ of $\mathrm{Cu}$ as $\mathrm{CuSO}_{4} \cdot 5 \mathrm{H}_{2} \mathrm{O} ; 25 \mathrm{mg}$ of $\mathrm{Fe}$ as $\mathrm{FeSO}_{4} \cdot 7 \mathrm{H}_{2} \mathrm{O} ; 60 \mathrm{mg}$ of $\mathrm{Zn}$ as $\mathrm{ZnSO}_{4} \cdot 7 \mathrm{H}_{2} \mathrm{O} ; 15 \mathrm{mg}$ of $\mathrm{Mn}$ as $\mathrm{MnSO}_{4} \cdot \mathrm{H}_{2} \mathrm{O} ; 0.6 \mathrm{mg}$ of I as Kl; $0.45 \mathrm{mg}$ of Se as $\mathrm{Na}_{2} \mathrm{SeO}_{3} \cdot 5 \mathrm{H}_{2} \mathrm{O}$ 


\begin{tabular}{|c|c|c|c|c|}
\hline \multirow[t]{2}{*}{ Diet } & \multicolumn{4}{|c|}{ n-6:n-3 PUFA ratio ${ }^{1}$} \\
\hline & $2: 1$ & $3: 1$ & $5: 1$ & $8: 1$ \\
\hline Avaliable AP & 0.20 & 0.20 & 0.20 & 0.20 \\
\hline Lysine (\%) & 0.88 & 0.88 & 0.88 & 0.88 \\
\hline Methionine + cystine (\%) & 0.60 & 0.60 & 0.60 & 0.60 \\
\hline Threonine (\%) & 0.58 & 0.58 & 0.58 & 0.58 \\
\hline
\end{tabular}

${ }^{1}$ To replace equivalent amounts of soybean oil, $1.6,0.8,0.4$ and $0.0 \%$ of linseed oil were used, making the dietary n-6:n-3 PUFA ratios about 2:1, 3:1,5:1 and 8:1, respectively

${ }^{2}$ Premix provided per kg diet: $8,000 \mathrm{IU}$ of vitamin $\mathrm{A}$ as retinol acetate; $15 \mathrm{mg}$ of vitamin $\mathrm{B}_{1}$ as thiamin; $30 \mathrm{mg}$ of vitamin $B_{2}$ as riboflavin; $15 \mathrm{mg}$ of vitamin $B_{6}$ as pyridoxine; $0.5 \mathrm{mg}$ of vitamin $B_{12}$ as cobalamin; $3000 \mathrm{IU}$ of vitamin $\mathrm{D}_{3}$ as cholecalciferol; $60 \mathrm{IU}$ of vitamin $\mathrm{E}$ as DL-a-tocopherol acetate; $35 \mathrm{mg}$ vitamin $\mathrm{K}$ as menadione; $175 \mathrm{mg}$ of nicotinic acid; $50 \mathrm{mg}$ of pantothenic acid; $2.5 \mathrm{mg}$ of biotin; $5 \mathrm{mg}$ of folic acid; $3 \mathrm{mg}$ of $\mathrm{Cu}$ as CuSO ${ }_{4} \cdot 5 \mathrm{H}_{2} \mathrm{O} ; 25 \mathrm{mg}$ of $\mathrm{Fe}$ as $\mathrm{FeSO}_{4} \cdot 7 \mathrm{H}_{2} \mathrm{O} ; 60 \mathrm{mg}$ of $\mathrm{Zn}$ as $\mathrm{ZnSO}_{4} \cdot 7 \mathrm{H}_{2} \mathrm{O} ; 15 \mathrm{mg}$ of $\mathrm{Mn}$ as $\mathrm{MnSO}_{4} \cdot \mathrm{H}_{2} \mathrm{O} ; 0.6 \mathrm{mg}$ of I as Kl; $0.45 \mathrm{mg}$ of Se as $\mathrm{Na}_{2} \mathrm{SeO}_{3} \cdot 5 \mathrm{H}_{2} \mathrm{O}$ 
Table 2

Fatty acid composition (\% total fatty acids) of the experimental diets

\begin{tabular}{|c|c|c|c|c|}
\hline \multirow[t]{2}{*}{ Diet } & \multicolumn{4}{|c|}{ n-6:n-3 PUFA ratio ${ }^{1}$} \\
\hline & $2: 1$ & $3: 1$ & $5: 1$ & $8: 1$ \\
\hline C8:0 & 0.13 & 0.09 & 0.05 & 0.05 \\
\hline C10:0 & 0.13 & 0.09 & 0.05 & 0.05 \\
\hline C12:0 & 1.19 & 0.93 & 0.55 & 0.50 \\
\hline $\mathrm{C} 14: 0$ & 0.37 & 0.39 & 0.26 & 0.23 \\
\hline C16:0 & 12.21 & 13.54 & 14.28 & 14.28 \\
\hline C16:1 & 0.33 & 0.27 & 0.14 & 0.23 \\
\hline C17:0 & 0.07 & 0.08 & 0.08 & 0.08 \\
\hline C18:0 & 3.41 & 3.81 & 4.07 & 3.24 \\
\hline C18:1 & 23.69 & 23.68 & 25.38 & 25.29 \\
\hline C18:2n-6 & 39.59 & 42.35 & 45.11 & 48.71 \\
\hline C18:3n-3 & 17.61 & 13.35 & 8.66 & 6.22 \\
\hline $\mathrm{C} 20: 0$ & 0.35 & 0.42 & 0.46 & 0.33 \\
\hline C20:1 & 0.26 & 0.27 & 0.29 & 0.23 \\
\hline $\mathrm{C} 22: 0$ & 0.20 & 0.28 & 0.34 & 0.24 \\
\hline$C 22: 4 n-6$ & 0.09 & 0.10 & 0.09 & 0.08 \\
\hline C23:0 & 0.08 & 0.13 & 0.06 & 0.07 \\
\hline C24:0 & 0.18 & 0.21 & 0.12 & 0.16 \\
\hline MUFA & 24.29 & 24.22 & 25.82 & 25.75 \\
\hline PUFA & 57.30 & 55.80 & 53.86 & 55.02 \\
\hline SFA & 18.42 & 19.98 & 20.33 & 19.24 \\
\hline$n-6: n-3$ & 2.25 & 3.18 & 5.22 & 7.84 \\
\hline \multicolumn{5}{|c|}{$\begin{array}{l}\text { MUFA monounsaturated fatty acids }(16: 1, \text { C18:1, 20:1), PUFA polyunsaturated fatty acids (C18:2, } \\
\text { C18:3, C22:4), SFA saturated fatty acids (C8:0 C10:0, C12:0, C14:0, C16:0, C17:0, C18:0, C20:0, C22:0, } \\
23: 0,24: 0)\end{array}$} \\
\hline
\end{tabular}

Sample collection 
The body weight and feed intake of the pigs were recorded after an overnight fast to calculate the average daily gain (ADG), average daily feed intake (ADFI) and feed conversion ratio (feed: gain, $F C R$ ).

At the end of the feeding test, blood samples were obtained via jugular vein puncture from one pig per pen and collected in $10 \mathrm{~mL}$ tubes. The serum was separated by centrifugation at $1,500 \times \mathrm{g}$ at $4{ }^{\circ} \mathrm{C}$ for 20 min then stored at $-20^{\circ} \mathrm{C}$ until analysis. The other pig per pen was randomly chosen and then stunned electrically ( $240 \mathrm{~V}, 800 \mathrm{~Hz}$ for $5-6 \mathrm{~s}$ ) then exsanguinated and eviscerated. Tissue samples (about $10 \mathrm{~g}$ ) were collected from the longissimus dorsi muscle (LM) and subcutaneous adipose tissue (SCAT) at the level of the last rib from the left-hand sides of the carcasses. The samples were cut into small pieces, snap-frozen in liquid $\mathrm{N}_{2}$ then stored at $-80^{\circ} \mathrm{C}$ for PCR analyses. The LM and SCAT samples (about $5 \mathrm{~g}$ ) were excised separately for analysis of their FA composition.

\section{Serum lipid and adipokine profiles}

The serum concentrations of triglyceride (TG), total cholesterol (TC), high-density lipoprotein cholesterol (HDL-C) and low-density lipoprotein cholesterol (LDL-C) were measured by an automatic biochemistry analyzer (Hitachi 747, Hitachi Ltd., Tokyo, Japan) with commercially available kits (Shenyang Dingsheng Trading Co., Ltd., Shenyang, China). The serum concentrations of leptin (LEP), adiponectin (APN) and interleukin 6 (IL-6) were measured using an automated microplate reader (Model 550, Bio-Rad, Hercules, CA, USA) with enzyme-linked immunosorbent assay (ELISA) kits (Shenyang Jinhui Technology Co., Ltd., Shenyang, China). All the procedures and conditions complied with the instructions provided with the kits.

\section{FA composition}

Samples of feed and tissues (approximately $5 \mathrm{~g}$ ) were extracted using a mixture of chloroform and methanol ( $\mathrm{v} / \mathrm{v} 2: 1$ ) to obtain FA methyl esters using the ISO 5509 method. After phase separation, $2 \mathrm{~mL}$ of the upper layer was transferred to a sample injection bottle. The FA composition of the samples was then measured by capillary gas chromatography (Agilent 6890-5973N; Agilent Technologies, Santa Clara, CA, USA). The chromatograph was equipped with a capillary column $(30.0 \mathrm{~m} \times 0.25 \mathrm{~mm}$ i.d. and polyethylene glycol-film, thickness $0.25 \mu \mathrm{m}$; Chrompack, Palo Alto, CA, USA) and a flame ionization detector. To optimize separation, the initial oven temperature was set at $80^{\circ} \mathrm{C}$, held for 1 min then increased to $220^{\circ} \mathrm{C}$ at $4{ }^{\circ} \mathrm{C} / \mathrm{min}$ up and held there for $14 \mathrm{~min}$. The carrier gas (helium) flow rate was $0.9 \mathrm{~mL} / \mathrm{min}$. Both the injector and detector were set at $230^{\circ} \mathrm{C}$ and the split ratio was $50: 1$. The peaks were identified using purified standards and different FA was quantified according the peak area, and expressed as percentage of total FA detected.

\section{Quantitative real-time PCR analysis}

Total RNA was isolated from the LM and SCAT samples using TRIzol Reagent (Sangon Biotech, Co., Ltd., Shanghai, China) according to the manufacturer's instructions. The quantity and purity of the RNA was determined by measuring the absorbance at 260 and $280 \mathrm{~nm}$ with their ratio used for assessing purity with a ratio close to 2.0 indicating a pure sample of RNA. The integrity of the measurements was confirmed by electrophoresis in $1.5 \%$ agarose gels. 
cDNA was generated from $700 \mathrm{ng}$ of DNase-treated RNA. The reaction mixture volume was $20 \mu \mathrm{L}$, containing $1 \mu \mathrm{L}$ RNA, $4 \mu \mathrm{L}$ buffer $(5 \times), 1 \mu \mathrm{L}$ dNTP mixture ( $0.5 \mathrm{mM}$ final concentration), $0.5 \mu \mathrm{L}$ RNase inhibitor (20 U), $1 \mu \mathrm{L}$ dTAP primer (100 pmol), $1 \mu \mathrm{L}$ Maxima RTase(200 U) and $11.5 \mu \mathrm{L}$ RNase-free doubledistilled water. The reverse transcriptase reaction conditions were $25^{\circ} \mathrm{C}$ for $10 \mathrm{~min}, 50^{\circ} \mathrm{C}$ for $30 \mathrm{~min}$ then $85^{\circ} \mathrm{C}$ for 5 min.

After reverse transcription, the cDNA was diluted by 6 times using sterilized double-distilled water. The relative expression levels of the target genes were determined using real-time fluorescence quantitative PCR (Roche, Rotkreuz, Switzerland). The reactions were prepared in a total volume of $20 \mu \mathrm{L}$, containing $0.8 \mu \mathrm{L}$ of reverse primer $(10 \mu \mathrm{M}), 2.0 \mu \mathrm{L}$ of the diluted CDNA, $10 \mu \mathrm{L}$ of SYBR Green qPCR Master Mix (Thermo Fisher Scientific, Inc., MA, USA) and $7.2 \mu \mathrm{L}$ of sterilized double-distilled water. The cycling conditions were $95^{\circ} \mathrm{C}$ for $3 \mathrm{~min}$, followed by 45 cycles of $95^{\circ} \mathrm{C}$ for $5 \mathrm{~s}$ and $60{ }^{\circ} \mathrm{C}$ for $30 \mathrm{~s}$, after which the fluorescence measurements were performed. The reaction was carried out with three duplicates of each sample.

The primer sequences for the reference genes ( $\beta$-actin), peroxisome proliferator-activated receptor $Y$ (PPARY), adipocyte fatty acid binding protein (aP2), lipoprotein lipase (LPL) and hormone-sensitive triglyceride lipase (HSL), were designed using Primer Premier 5.0 software (Premier Biosoft, San Francisco, CA, USA) and are listed in Table 3. The comparative CT method ( ${ }^{-\triangle \Delta C t}$ method) was used to calculate the mRNA expression of genes, with the value standing for the $n$-fold difference relative to the calibrator $[9,10]$.

Table 3

Primers used for Real-time PCR

\begin{tabular}{|c|c|c|c|c|}
\hline Gene name & $\begin{array}{l}\text { Gene } \\
\text { symbol }\end{array}$ & Primers & Sequences $\left(5^{\prime}-3^{\prime}\right)$ & $\begin{array}{l}\text { Size } \\
\text { (bp) }\end{array}$ \\
\hline \multirow{2}{*}{$\begin{array}{l}\text { Peroxisome proliferater- activated } \\
\text { receptor } Y\end{array}$} & PPARY & Forward & ACAGACCTCAGGCAGATCGT & 83 \\
\hline & & Reverse & GGGTGAAGGCTCATGTCTGT & \\
\hline \multirow{2}{*}{$\begin{array}{l}\text { Adipocyte fatty acid binding } \\
\text { protein }\end{array}$} & aP2 & Forward & ACAGGAAAGTCAAGAGCACCA & 126 \\
\hline & & Reverse & TGATACATTCCACCACCAACTT & \\
\hline \multirow[t]{2}{*}{ Lipoprotein lipase } & LPL & Forward & ACGACGCAGATTTTGTAGACG & 124 \\
\hline & & Reverse & CCTGGTTGGAAAGTGCCTC & \\
\hline \multirow{2}{*}{$\begin{array}{l}\text { Hormone-sensitive triglayceride } \\
\text { lipase }\end{array}$} & HSL & Forward & CAGGTGTCTTTGCGGGTATT & 234 \\
\hline & & Reverse & CGAGTTCGGCCAGGTTGT & \\
\hline \multirow[t]{2}{*}{$\beta$-actin } & ACTB & Forward & CCAAAGCCAACCGTGAGA & 106 \\
\hline & & Reverse & CGGCCAGAGGCGTACAG & \\
\hline
\end{tabular}

\section{Statistical analysis}


All data were analyzed by one-way analysis of variance (ANOVA) using SPSS version 19.0 for Windows (IBM Corp., Armonk, NY, USA). The differences between the means were analyzed using Duncan's multiple comparisons. Probability values less than 0.05 were considered to be statistically significant. The standard error of the mean (SEM) and the significance of the test were also calculated. For growth performance, the pen was used as the experimental unit while for the blood analysis, tissue FA composition and gene expression, the individual pig was used as the experimental unit.

\section{Results}

\section{Growth performance}

The growth performance of pigs fed diets with different $n-6: n-3$ PUFA ratios are shown in Table 4. Pigs fed the diet with n-6:n-3 PUFA ratios of 3:1 and 5:1 had a higher ADG $(P<0 \cdot 05)$ than those fed the diet with n-6:n-3 PUFA ratios of 1:1 and 8:1. Pigs fed the diet with an n-6:n-3 PUFA ratio of 3:1 exhibited a higher ADFI $(P<0.05)$ than those fed the diet with n-6:n-3 PUFA ratios of 5:1 and 8:1. However, pigs fed the diet with an n-6:n-3 PUFA ratio of 5:1 had a lower FCR $(P<0.05)$ than those fed the diet with an n-6:n-3 PUFA ratio of 2:1.

Table 4

Effects of dietary n-6:n-3 PUFA ratios on the growth performance of finishing pigs

\begin{tabular}{|c|c|c|c|c|c|c|}
\hline \multirow[t]{2}{*}{ Items } & \multicolumn{4}{|c|}{ n-6:n-3 PUFA ratio ${ }^{1}$} & \multirow{2}{*}{$\begin{array}{l}\text { SEM } \\
N=6\end{array}$} & \multirow[t]{2}{*}{ P-value } \\
\hline & $2: 1$ & $3: 1$ & $5: 1$ & $8: 1$ & & \\
\hline Initial weight (kg) & 68.50 & 69.44 & 68.93 & 68.28 & 0.48 & 0.365 \\
\hline Final weight (kg) & $115.41^{b}$ & $123.89^{a}$ & $121.58^{a}$ & $115.94^{b}$ & 0.95 & $<0.001$ \\
\hline ADG $(\mathrm{kg} / \mathrm{d})$ & $1.04^{b}$ & $1.21^{\mathrm{a}}$ & $1.17^{a}$ & $1.06^{b}$ & 0.02 & $<0.001$ \\
\hline $\operatorname{ADFI}(\mathrm{kg} / \mathrm{d})$ & $2.86^{\mathrm{ab}}$ & $2.95^{\mathrm{a}}$ & $2.76^{\mathrm{bc}}$ & $2.68^{c}$ & 0.04 & $<0.001$ \\
\hline FCR (feed: gain) & $2.75^{\mathrm{a}}$ & $2.44^{\mathrm{ab}}$ & $2.36^{\mathrm{b}}$ & $2.52^{\mathrm{ab}}$ & 0.05 & $<0.001$ \\
\hline
\end{tabular}

$A D G$ average daily gain, $A D F /$ average daily feed intake, $F C R$ feed conversion ratio (feed: gain), SEM standard error of the mean

${ }^{1}$ To replace equivalent amounts of soybean oil, $1.6,0.8,0.4$ and $0.0 \%$ of linseed oil were used, making the dietary $n-6: n-3$ PUFA ratios about 2:1, 3:1,5:1 and 8:1, respectively

$a, b, c$ Values within a row without a common superscript letters were significantly different $(p<0.05)$

\section{Serum lipid and adipokine profiles}

The serum lipid and cytokine concentrations of pigs fed diets with different n-6:n-3 PUFA ratios are shown in Table 5. Pigs fed the diet with an n-6:n-3 PUFA ratio of 3:1 had a higher concentration of TG $(P<0.05)$ 
than those fed the diet with an n-6:n-3 PUFA ratio of 2:1, which had a lower concentration of TG $(P<0 \cdot 05)$ than pigs fed the diet with n-6:n-3 PUFA ratios of $5: 1$ and 8:1. Pigs fed the diet with n-6:n-3 PUFA ratios of 3:1 and 5:1 had a higher the concentration of TC $(P<0 \cdot 05)$ than pigs fed the diet with an n-6:n-3 PUFA ratio of 2:1, which had a lower the concentration of TC $(P<0.05)$ than pigs fed the diet with an n-6:n-3 PUFA ratio of 8:1. Although there were no significant differences $(P>0.05)$ in the concentration of HDL-C and LDL-C between the groups, the HDL-C:LDL-C was increased in pigs fed the diet with an n-6:n-3 PUFA ratio of 2:1.

Table 5

Effects of dietary n-6:n-3 PUFA ratios on serum lipid and adipokines of finishing pigs

\begin{tabular}{|c|c|c|c|c|c|c|}
\hline \multirow[t]{2}{*}{ Items } & \multicolumn{4}{|c|}{ n-6:n-3 PUFA ratio ${ }^{1}$} & \multirow{2}{*}{$\begin{array}{l}\text { SEM } \\
\mathrm{N}=6\end{array}$} & \multirow[t]{2}{*}{ P-value } \\
\hline & $2: 1$ & $3: 1$ & $5: 1$ & $8: 1$ & & \\
\hline $\mathrm{TG}(\mathrm{mmol} / \mathrm{L})$ & $0.17^{c}$ & $0.25^{b}$ & $0.30^{a}$ & $0.33^{a}$ & 0.02 & $<0.001$ \\
\hline $\mathrm{TC}(\mathrm{mmol} / \mathrm{L})$ & $2.95^{\mathrm{C}}$ & $3.61^{b}$ & $3.64^{b}$ & $4.11^{\mathrm{a}}$ & 0.11 & $<0.001$ \\
\hline $\mathrm{HDL}-\mathrm{C}(\mathrm{mmol} / \mathrm{L})$ & 3.84 & 3.80 & 3.72 & 3.69 & 0.05 & 0.189 \\
\hline LDL-C (mmol/L) & 1.47 & 1.54 & 1.54 & 1.55 & 0.03 & 0.370 \\
\hline HDL:LDL & $2.61^{\mathrm{a}}$ & $2.47^{b}$ & $2.41^{b}$ & $2.38^{b}$ & 0.04 & 0.009 \\
\hline LEP (mg/L) & $7.65^{c}$ & $8.07^{c}$ & $11.11^{b}$ & $15.04^{\mathrm{a}}$ & 0.47 & $<0.001$ \\
\hline IL-6 (mg/L) & $3.43^{b}$ & $6.58^{\mathrm{a}}$ & $6.61^{\mathrm{a}}$ & $6.62^{\mathrm{a}}$ & 0.07 & $<0.001$ \\
\hline APN (mg/L) & $23.24^{\mathrm{a}}$ & $21.50^{\mathrm{a}}$ & $11.07^{b}$ & $11.32^{\mathrm{b}}$ & 0.65 & $<0.001$ \\
\hline \multicolumn{7}{|c|}{$\begin{array}{l}T G \text { triglyceride, } T C \text { total cholesterol, } H D L-C \text { high density lipoprotein cholesterol, } L D L-C \text { low density } \\
\text { lipoprotein cholesterol, } L E P \text { leptin, } I L-6 \text { interleukin- } 6, A P N \text { adiponectin, } S E M \text { standard error of the mean }\end{array}$} \\
\hline \multicolumn{7}{|c|}{$\begin{array}{l}{ }^{1} \text { To replace equivalent amounts of soybean oil, } 1.6,0.8,0.4 \text { and } 0.0 \% \text { of linseed oil were used, making } \\
\text { the dietary } n-6: n-3 \text { PUFA ratios about } 2: 1,3: 1,5: 1 \text { and } 8: 1 \text {, respectively }\end{array}$} \\
\hline \multicolumn{7}{|c|}{ a,b,c Values within a row without a common superscript letters were significantly different $(p<0.05)$} \\
\hline
\end{tabular}

The concentrations of LEP and IL-6 of pigs fed the diet with an n-6:n-3 PUFA ratio of 2:1 decreased significantly $(P<0 \cdot 05)$, compared with those fed the diet with n-6:n-3 PUFA ratios of 5:1 and 8:1. In contrast, the concentration of APN of pigs fed the diet with an n-6:n-3 PUFA ratio of 2:1 increased significantly $(P<0.05)$ compared with those fed the diet with n-6:n-3 PUFA ratios of 5:1 and 8:1.

\section{Tissue FA composition}

The FA composition of the LM of pigs fed diets with different n-6:n-3 PUFA ratios is shown in Table 6. The concentrations of MUFA including C18:1, PUFA including C20:2n-6 and C20:4n-6, SFA including C8:0, C10:0, C16:0, C17:0 and C18:0 were unaffected $(P>0.05)$ by the dietary n-6:n-3 PUFA ratios. The highest 
concentration of C16:1 $(P<0.05)$ was obtained in the LM of pigs fed with a dietary n-6:n-3 PUFA ratio of 3:1, while the concentrations of $\mathrm{C} 14: 0, \mathrm{C} 18: 3 \mathrm{n}-3, \mathrm{C} 20: 0$ and $\mathrm{C} 20: 1$ were highest $(P<0.05)$ in pigs fed the diet with an n-6:n-3 PUFA ratio of 2:1. However, the concentration of $C 18: 2 n-6$ was the highest in pigs fed the diet with an n-6:n-3 PUFA ratio of 8:1 $(P<0 \cdot 05)$. As expected, the n-6:n-3 PUFA ratio in the LM of pigs increased with increasing dietary n-6:n-3 PUFA ratios $(P<0 \cdot 05)$. 
Table 6

Effects of dietary n-6:n-3 PUFA ratios on fatty acids composition of the LM of pigs

\begin{tabular}{|c|c|c|c|c|c|c|}
\hline \multirow[t]{2}{*}{ Items } & \multicolumn{4}{|c|}{ n-6:n-3 PUFA ratio ${ }^{1}$} & \multirow{2}{*}{$\begin{array}{l}\text { SEM } \\
N=6\end{array}$} & \multirow[t]{2}{*}{ P-value } \\
\hline & $2: 1$ & $3: 1$ & $5: 1$ & $8: 1$ & & \\
\hline C8:0 & 0.11 & 0.10 & 0.10 & 0.11 & 0.01 & 0.361 \\
\hline C10:0 & 0.13 & 0.12 & 0.12 & 0.11 & 0.01 & 0.206 \\
\hline C14:0 & $1.79^{a}$ & $1.54^{\mathrm{b}}$ & $1.36^{\mathrm{C}}$ & $1.21^{d}$ & 0.04 & $<0.001$ \\
\hline C16:0 & 25.55 & 25.04 & 25.22 & 26.34 & 0.55 & 0.379 \\
\hline C16:1 & $2.55^{\mathrm{ab}}$ & $3.10^{\mathrm{a}}$ & $2.99^{a}$ & $2.07^{b}$ & 0.20 & 0.005 \\
\hline C17:0 & 0.16 & 0.16 & 0.14 & 0.15 & 0.02 & 0.811 \\
\hline C18:0 & 13.44 & 14.06 & 13.67 & 14.07 & 0.40 & 0.853 \\
\hline C18:1 & 37.65 & 37.29 & 36.70 & 37.06 & 1.41 & 0.970 \\
\hline$C 18: 2 n-6$ & $13.42^{b}$ & $14.76^{\mathrm{ab}}$ & $15.67^{a}$ & $16.14^{\mathrm{a}}$ & 0.55 & 0.046 \\
\hline C18:3n-3 & $3.06^{a}$ & $2.35^{b}$ & $2.31^{b}$ & $1.21^{\mathrm{c}}$ & 0.14 & $<0.001$ \\
\hline C20:0 & $0.28^{a}$ & $0.15^{c}$ & $0.18^{\mathrm{bc}}$ & $0.21^{b}$ & 0.02 & $<0.001$ \\
\hline C20:1 & $0.93^{a}$ & $0.51^{\mathrm{b}}$ & $0.60^{b}$ & $0.50^{\mathrm{b}}$ & 0.04 & $<0.001$ \\
\hline$C 20: 2 n-6$ & 0.53 & 0.45 & 0.50 & 0.45 & 0.03 & 0.124 \\
\hline$C 20: 4 n-6$ & 0.40 & 0.36 & 0.44 & 0.38 & 0.02 & 0.155 \\
\hline MUFA & 41.07 & 40.90 & 40.29 & 39.63 & 1.42 & 0.935 \\
\hline PUFA & 17.97 & 17.92 & 18.92 & 18.18 & 0.55 & 0.557 \\
\hline SFA & 41.46 & 41.17 & 40.79 & 42.19 & 0.74 & 0.229 \\
\hline$n-6: n-3$ & $4.87^{b}$ & $6.63^{b}$ & $7.19^{b}$ & $14.02^{\mathrm{a}}$ & 0.71 & $<0.001$ \\
\hline \multicolumn{7}{|c|}{$\begin{array}{l}\angle M \text {, lingissimus dorsi muscle, MUFA monounsaturated fatty acid, PUFA polyunsaturated fatty acids, } \\
\text { SFA saturated fatty acids, SEM standard error of the mean. }\end{array}$} \\
\hline \multicolumn{7}{|c|}{$\begin{array}{l}{ }^{1} \text { To replace equivalent amounts of soybean oil, } 1.6,0.8,0.4 \text { and } 0.0 \% \text { of linseed oil were used, making } \\
\text { the dietary } n-6: n-3 \text { PUFA ratios about } 2: 1,3: 1,5: 1 \text { and } 8: 1 \text {, respectively }\end{array}$} \\
\hline
\end{tabular}

The FA composition of the SCAT of pigs fed diets with different n-6:n-3 PUFA ratios is shown in Table 7. The concentrations of MUFA including C18:1, PUFA including C20:2n-6, C20:3n-6 and C20:4n-6, SFA 
including $\mathrm{C} 10: 0, \mathrm{C} 12: 0$ and $\mathrm{C} 16: 0$ were unaffected $(P>0.05)$ by the dietary n-6:n-3 PUFA ratios. Pigs fed a diet with an n-6:n-3 PUFA ratio of 8:1 exhibited the highest C14:0 and C18:2n-6 concentrations $(P<0.05)$ and the lowest $\mathrm{C} 16: 1$ concentration $(P<0.05)$ of the treatment groups. However, the concentrations of C17:0, 18:0, C18:3n-6, C20:0 and C20:1 were highest $(P<0 \cdot 05)$ in pigs fed the diet with an n-6:n-3 PUFA ratio of 2:1. Similar to the changes in the LM, the ratios of n-6:n-3 PUFA in the SCAT samples also increased with increasing dietary n-6:n-3 PUFA ratios $(P<0 \cdot 05)$. 
Table 7

Effects of dietary n-6:n-3 PUFA ratios on FA composition of the SCAT of pigs

\begin{tabular}{|c|c|c|c|c|c|c|}
\hline \multirow[t]{2}{*}{ Items } & \multicolumn{4}{|c|}{ n-6:n-3 PUFA ratio ${ }^{1}$} & \multirow{2}{*}{$\begin{array}{l}\text { SEM } \\
N=6\end{array}$} & \multirow[t]{2}{*}{ P-value } \\
\hline & $2: 1$ & $3: 1$ & $5: 1$ & $8: 1$ & & \\
\hline C10:0 & 0.06 & 0.07 & 0.06 & 0.08 & 0.01 & 0.078 \\
\hline C12:0 & 0.11 & 0.10 & 0.09 & 0.11 & 0.01 & 0.174 \\
\hline C14:0 & $1.29^{b}$ & $1.19^{c}$ & $1.15^{\mathrm{c}}$ & $1.36^{\mathrm{a}}$ & 0.02 & $<0.001$ \\
\hline C16:0 & 23.49 & 22.65 & 22.62 & 23.69 & 0.82 & 0.711 \\
\hline $\mathrm{C} 16: 1$ & $1.34^{\mathrm{a}}$ & $1.44^{\mathrm{a}}$ & $1.35^{\mathrm{a}}$ & $1.19^{b}$ & 0.04 & 0.001 \\
\hline C17:0 & $0.20^{\mathrm{a}}$ & $0.16^{\mathrm{b}}$ & $0.22^{\mathrm{a}}$ & $0.20^{\mathrm{a}}$ & 0.01 & 0.003 \\
\hline C18:0 & $16.04^{\mathrm{a}}$ & $12.49^{b}$ & $14.03^{b}$ & $14.03^{b}$ & 0.58 & 0.003 \\
\hline C18:1 & 29.46 & 33.79 & 31.14 & 30.66 & 1.10 & 0.070 \\
\hline$C 18: 2 n-6$ & $21.56^{\mathrm{b}}$ & $23.49^{a b}$ & $24.80^{a}$ & $25.26^{a}$ & 0.72 & 0.007 \\
\hline C18:3n-3 & $4.34^{\mathrm{a}}$ & $2.76^{b}$ & $2.71^{\mathrm{b}}$ & $1.78^{\mathrm{C}}$ & 0.26 & $<0.001$ \\
\hline $\mathrm{C} 20: 0$ & $0.25^{a}$ & $0.17^{c}$ & $0.21^{b}$ & $0.19^{b c}$ & 0.01 & $<0.001$ \\
\hline C20:1 & $0.92 a$ & $0.69 b$ & $0.58 c$ & $0.56 c$ & 0.04 & $<0.001$ \\
\hline$C 20: 2 n-6$ & 0.68 & 0.76 & 0.78 & 0.65 & 0.05 & 0.179 \\
\hline$C 20: 3 n-6$ & 0.08 & 0.08 & 0.08 & 0.08 & 0.01 & 0.960 \\
\hline$C 20: 4 n-6$ & 0.18 & 0.15 & 0.16 & 0.16 & 0.01 & 0.225 \\
\hline MUFA & 31.42 & 35.91 & 33.07 & 32.41 & 1.12 & 0.072 \\
\hline PUFA & 26.84 & 28.24 & 28.53 & 27.93 & 0.72 & 0.391 \\
\hline SFA & $41.44^{\mathrm{a}}$ & $36.83^{c}$ & $38.38^{b c}$ & $40.66^{a b}$ & 0.83 & 0.006 \\
\hline$n-6: n-3$ & $5.18^{c}$ & $6.56^{\mathrm{b}}$ & $9.53^{b}$ & $14.69^{a}$ & 1.37 & 0.003 \\
\hline \multicolumn{7}{|c|}{$\begin{array}{l}\text { SCAT subcutaneous adipose tissue, MUFA monounsaturated fatty acid, PUFA polyunsaturated fatty } \\
\text { acids, SFA saturated fatty acids, SEM standard error of the mean }\end{array}$} \\
\hline \multicolumn{7}{|c|}{$\begin{array}{l}{ }^{1} \text { To replace equivalent amounts of soybean oil, } 1.6,0.8,0.4 \text { and } 0.0 \% \text { of linseed oil were used, making } \\
\text { the dietary n-6:n-3 PUFA ratios about } 2: 1,3: 1,5: 1 \text { and } 8: 1 \text {, respectively }\end{array}$} \\
\hline
\end{tabular}


The relative mRNA expression levels of genes in the LM of pigs fed diets with different n-6:n-3 PUFA ratios are shown in Table 8. Pigs fed the diet with an n-6:n-3 PUFA ratio of 5:1 exhibited up-regulated gene expression levels of the PPARy and LPL $(P<0.05)$ compared with those fed diets with n-6:n-3 PUFA ratios of 2:1, 3:1 and 8:1. The expression level of aP2 was unaffected by the dietary n-6:n-3 PUFA ratios $(P>$ $0.05)$. The diet with an n-6:n-3 PUFA ratio of 2:1 markedly up-regulated the expression level HSL $(P<$ $0.05)$.

Table 8

Effects of dietary n-6:n-3 PUFA ratios on the relative mRNA expression levels of genes in the LM of pigs

\begin{tabular}{|lllllll|}
\hline Items & n-6:n-3 PUFA ratio & & & SEM & P-value \\
\hline PPARY & $2: 1$ & $3: 1$ & $5: 1$ & $8: 1$ & $N=6$ & \\
\hline LPL & $1.01^{\mathrm{c}}$ & $1.81^{\mathrm{b}}$ & $2.57^{\mathrm{a}}$ & $1.18^{\mathrm{c}}$ & 0.11 & $<0.001$ \\
\hline aP2 & $1.00^{\mathrm{b}}$ & $0.89^{\mathrm{b}}$ & $1.52^{\mathrm{a}}$ & $0.93^{\mathrm{b}}$ & 0.04 & $<0.001$ \\
\hline HSL & 0.99 & 0.95 & $1.07^{\mathrm{a}}$ & 0.88 & 0.05 & 0.186 \\
\hline
\end{tabular}

$\angle M$ longissimus dorsi muscle, $P P A R y$ peroxisome proliferator-activated receptor- $y, L P L$ lipoprotein lipase, aP2 adipocyte fatty acid binding protein, HSL hormone-sensitive lipase, SEM standard error of the mean

${ }^{1}$ To replace equivalent amounts of soybean oil, $1.6,0.8,0.4$ and $0.0 \%$ of linseed oil were used, making the dietary $n-6: n-3$ PUFA ratios about $2: 1,3: 1,5: 1$ and $8: 1$, respectively

$a, b, c$ Values within a row without a common superscript letters were significantly different $(P<0 \cdot 05)$

The relative mRNA expression levels of genes in the SCAT of pigs fed diets with different n-6:n-3 PUFA ratios are shown in Table 9. Consistent with the gene changes in the LM, pigs fed the diet with an n-6:n-3 PUFA ratio of 5:1 significantly up-regulated the gene expression levels of the PPARY and LPL $(P<0.05)$ compared with those fed diets with n-6:n-3 PUFA ratio of 2:1, 3:1 and 8:1. However, the gene expression levels of aP2 and HSL of pigs fed the diet with n-6:n-3 PUFA ratios of 3:1 and 5:1, respectively, was significantly up-regulated $(P<0.05)$. 
Table 9

Effects of dietary n-6:n-3 PUFA ratios on the relative mRNA expression levels of genes in the SCAT of pigs

\begin{tabular}{|lllllll|}
\hline Items & \multicolumn{2}{l}{ n-6:n-3 PUFA ratio } & & & SEM & P-value \\
\hline PPARY & $2: 1$ & $3: 1$ & $5: 1$ & $8: 1$ & $\mathrm{~N}=6$ & \\
\hline LPL & $1.00^{\mathrm{b}}$ & $1.19^{\mathrm{b}}$ & $1.90^{\mathrm{a}}$ & $1.43^{\mathrm{b}}$ & 0.13 & 0.007 \\
\hline aP2 & $1.00^{\mathrm{c}}$ & $1.80^{\mathrm{b}}$ & $2.66^{\mathrm{a}}$ & $1.91^{\mathrm{b}}$ & 0.06 & $<0.001$ \\
\hline HSL & $1.00^{\mathrm{b}}$ & $1.67^{\mathrm{a}}$ & $0.83^{\mathrm{b}}$ & $0.72^{\mathrm{b}}$ & 0.12 & 0.002 \\
\hline
\end{tabular}

SCAT subcutaneous adipose tissue, PPARy peroxisome proliferator-activated receptor-y, $L P L$ lipoprotein lipase, aP2 adipocyte fatty acid binding protein, HSL hormone-sensitive lipase, SEM standard error of the mean

${ }^{1}$ To replace equivalent amounts of soybean oil, $1.6,0.8,0.4$ and $0.0 \%$ of linseed oil were used, making the dietary n-6:n-3 PUFA ratios about 2:1, 3:1, 5:1 and 8:1, respectively

a,b,c,d Mean values with unlike superscript letters within a row were significantly different $(P<0.05)$

\section{Discussion}

\section{Effects of dietary n-6:n-3 PUFA ratios on growth performance}

Previous studies have shown that replacing part of the metabolizable energy content of a diet with different fat mixtures does not change the energy content or nutritional value of the diet so does not affect the growth performance and carcass quality of finishing pigs [11, 12]. It has been reported that the absence of a positive effect on growth performance when increasing dietary n-3 PUFA intake may be caused by similar dietary metabolizable energy contents [8]. However, the results of the present study indicated that dietary n-6:n-3 PUFA ratios of 3:1 to 5:1 improved growth performance, which agreed with previous reports showing that a diet with n-6:n-3 PUFA ratios of 2.5 to $5: 1$ improved the growth performance and health of animals $[13,14]$. We also observed that pigs fed the diet with an n-6: n-3 PUFA ratio of 2:1 exhibited a lower ADG and higher FCR than the other groups. This could be explained by the higher content of n-3 PUFA being oxidized preferentially over n-6 PUFA for energy production, therefore decreasing growth performance. The reasons for these inconsistent results may be related to feed ingredients, genetics or the breed of the pigs. Differences in the type of n-3 PUFA, dosage and duration may also have contributed to differences in outcomes.

\section{Effects of dietary n-6:n-3 PUFA ratios on serum lipid and adipokine profiles}


Blood TC levels reflect the nutritional status of animals and are positively associated with adiposity [15], while HDL levels are inversely correlated with the risk of coronary artery disease because HDL partially inhibits the uptake and degradation of LDL, and suppresses LDL-induced changes in sterol level [16]. Therefore, it is generally believed that lower concentrations of blood TG, TC and LDL-C and higher concentration of blood HDL-C improve the health of humans and animals [17]. The n-3 PUFA are considered to increase HDL-C and decrease TG by increasing the synthesis of HDL and clearance of TG $[18,19]$. As expected, lower serum TG and TC levels and higher HDL-C:LDL-C ratios were observed in pigs fed the diet with lower n-6:n-3 PUFA ratios compared with those in pigs fed a diet with a higher n-6:n-3 PUFA ratio. This agreed with the observations of previous studies, where blended oils with lower $n-6: n-3$ PUFA ratios decreased the serum concentrations of TG, TC and LDL-C and increased the concentration of HDL-C $[20,21]$. It is reported that dietary n-6:n-3 PUFA ratios of $1: 1$ and $5: 1$ facilitated the absorption and use of FA and exerted beneficial effects on lipid metabolism in pigs [14]. In terms of the mechanisms underlying the hypolipidemic effects of n-3 PUFA, it can be presumed that n-3 PUFA-mediated reductions in the concentration of the circulating TG included inhibiting hepatic TG synthesis and secretion, reducing the intestinal and hepatic apolipoprotein B species, which are responsible for TG elimination, and increasing LPL activity [8]. The hypolipidemic effect of dietary n-3 PUFA is also associated with the stimulation of FA oxidation in the liver and, to a smaller extent, in skeletal muscle, which may ameliorate dyslipidemia, tissue lipid accumulation and insulin action.

Several secretory adipokines such as LEP, APN and IL- 6 are synthesized in adipose tissue. LEP is expressed and secreted in proportion to the number and size of adipocytes and circulates in the body at a concentration highly correlated with the mass of body fat and participates in the regulation of food intake and energy expenditure. Studies have shown that n-3 FA intake is negatively correlated with changes in plasma LEP concentration [22]. Our results showed that the serum concentration of LEP decreased significantly with a decreasing dietary n-6:n-3 PUFA ratio. Similar effects of the n-6:n-3 PUFA ratio on LEP have also been observed in rats [22] and mice [23]. However, other studies on rodents and cultured adipocytes have shown that n-3 PUFA (EPA) increases the production of LEP [24, 25]. Studies assessing the role of n-3 PUFA in weight maintenance have found no significant effect on weight or blood LEP concentrations between n-3 PUFA supplemented subjects [26, 27]. The n-3 PUFA mediated effects on LEP depend on a number of factors, such as diet composition and energy balance, which could thus cause conflicting results. Physical activity is also important for blood LEP concentrations, but independent of fat mass [28].

IL-6, like the tumor necrosis factor - $a$ (TNF-a), is also an important pro-inflammatory cytokine that can stimulate $T$ and $B$ lymphocyte proliferation and initiate the production of several inflammatory mediators, thus leading to an inflammatory response. IL- 6 also antagonizes anabolic growth factors and thus suppresses growth [29]. Studies have revealed that most n-3 PUFA are anti-inflammatory and decrease the production of these inflammatory cytokines, whereas n-6 PUFA are pro-inflammatory and increases their production $[30,31]$. The present study showed that diets with a lower $n-6: n-3$ PUFA ratio $(2: 1)$ could inhibit the production of IL-6, agreeing with the results of previous studies, which reported that the serum concentrations of IL-6 decreased with decreasing n-6:n-3 PUFA ratio (from 20:1 to 1:1) [13,32]. In humans 
and in vitro, n-3 PUFA have also been reported to reduce cytokines, including IL-6 and TNF-a [33], which are both elevated in obesity. The anti-inflammatory effects of n-3 PUFA may help to protect against atherosclerosis and mortality related to cardiovascular diseases [29].

APN is one of the most abundant adipokines and plays a central role in lipid metabolism, exerting protective effects with its insulin-sensitizing, antiatherogenic and anti-inflammatory properties [34]. Studies have also demonstrated that the serum concentration of APN is negatively correlated with body mass index, type 2 diabetes and cardiovascular diseases [35, 36]. In the present study, lower n-6:n-3 PUFA ratios (2:1 and 3:1) promoted the production of APN. Mice tests have found that as the n-6:n-3 PUFA ratio decreases, the serum concentration of APN increases in a dose-dependent manner and also in a PPARYdependent manner $[37,38]$. Human studies have found significant increases in human blood concentration of APN following the consumption of n-3 PUFA regardless of body weight, leading to speculation that the anti-inflammatory properties of n-3 PUFA may induce an increase in adipocyte APN production $[39,40]$. It has also been demonstrated that n-3 PUFA may influence the concentration of APN directly by interacting with transcription factors, or indirectly via unknown mechanisms linked to FA oxidation, synthesis or storage $[13,22]$.

\section{Effects of dietary n-6:n-3 PUFA ratios on tissue FA composition}

FA in tissue play an important role in the flavor, nutritional value and oxidative stability of meat [41]. Therefore, improving FA composition has a vital role in producing high-quality pork meat with a superior nutritional value for human consumption. The FA composition of pork is largely determined by the FA digested by the animal and reflects long-term intake [42]. The relative proportions of these FA are reflected in the FA composition of the deposited fat. Previous studies have confirmed the importance of the n-6:n-3 PUFA ratio and the view that decreasing the ratio leads to increasing the n-3 PUFA content and the protection against obesity and related diseases such as inflammation, hepatic steatosis, coronary heart disease, and cardiovascular diseases [43]. In the present study, as expected, the C18:3n-3 concentration of the LM and SCAT samples was significantly enhanced with decreasing dietary n-6:n-3 PUFA ratios, while the $C 18: 2 n-6$ and n-6:n-3 PUFA ratios decreased correspondingly. The concentrations of most MUFA were higher in pigs fed a diet with an n-6:n-3 PUFA ratio of 2:1 than in pigs of the other groups. This can be explained by the linseed oil used in the present study being characterized by a high n-3 PUFA content, especially C18:3n-3, which represents about $45-55 \%$ of total FA, a moderate MUFA content and low SFA content, whereas soybean oil contains high C18:2n-6 content. Studies have confirmed that reducing dietary $n-6$ and elevating n-3 PUFA are highly successful at raising the quantities of $18: 3 n-3$ and the n-3 long-chain PUFA in pork, thus supplying valuable n-3 PUFA to the human diet [8]. It has been reported that adding oils rich in n-3 PUFA to pig feed can increase the deposition of these FA in the meat $[11,44]$. C18:2n-6 and C18:3n-3 are converted into their derivative n- 6 or n-3 long-chain PUFA through $\Delta 6$ and $\Delta 5$ fatty acyl desaturase (Fad) and elongations [16], respectively. The present study and previous publications suggest that diets with a higher proportion of n-3 PUFA ratio decrease the conversion of C18:2n-6 to n-6 long-chain PUFA, because the enzymes act preferentially on n-3 PUFA. In contrast, diets

Page 19/28 
with a higher n-6 PUFA have adequate $\Delta 6$ Fad activity thus ensuring the elongation of $C 18: 2 n-6$ and their conversion into long-chain PUFA.

\section{Effects of dietary n-6:n-3 PUFA ratios on gene expression of tissue}

Lipogenesis and lipolysis are major factors affecting fat accumulation in tissues. Dietary supplementation with fat or FA can modify the FA composition of tissues by altering the expression of fat metabolism genes [13]. FA or their derivatives may interact with nuclear receptor proteins that bind to certain regulatory regions of DNA and thereby alter the transcription of the target genes [22]. Both n-3 and n-6 PUFA can bind and/or regulate transcriptional factors that control genes involved in pre-adipocyte differentiation. PPARy, a member of the ligand-activated PPAR subfamily of nuclear hormone receptors, is highly expressed during the late stage of white adipocyte differentiations. The PPARy signaling pathway is mainly associated with lipid metabolism, dipocyte differentiation, thermogenesis and gluconeogenesis via the modulation of a number of target genes. When PUFA are added to the diet, the main effect of PPARy on glucose metabolism is to increase the activity of glyceraldehyde 3-phosphate dehydrogenase (G3PDH) involved in TG synthesis rather than the induction of de novolipogenesis [45]. Furthermore, PPARy senses incoming non-esterified long-chain PUFA and regulates the genes for long-chain PUFA oxidation then induces the pathways to store long-chain PUFA as TG during fasting and endurance exercise in skeletal muscle. Thus, the decrease in PPARy expression of the LM and SCAT samples in the present study may be consistent with the trend towards lower concentrations of serum TG, TC with decreasing dietary n-6:n-3 PUFA ratios. This indicates that n-3 PUFA can suppress the transcription of lipogenic genes and lipogenesis by functioning as natural ligands for PPARY [46]. However, the present study showed that an n-6:n-3 PUFA ratio of 5:1 rather than 8:1 led to the highest expression level of PPARy, suggesting that an optimal n-6:n-3 PUFA ratio can promote adipogenesis and a healthy expansion of adipose tissue during positive energy balance, and a metabolically healthy phenotype. Studies on clonal adipocytes (3T3-L1) have also demonstrated the up-regulation of PPARy expression, adipogenesis and lipid droplet formation after supplementation with n-3 PUFA [47].

aP2 and LPL are two important target genes in the PPARy signaling pathway and play important role in the transport of FA $[48,49]$. aP2 is secreted from both macrophages and adipocytes, functions as an adipokine, and participates in FA uptake and the transport process of intramuscular adipocytes [50]. LPL is the enzyme mainly responsible for the hydrolysis of TG from triacylglycerol-rich lipoprotein particles from cycling and releasing free FA for muscle uptake [51], so is responsible for fat mobilization and deposition of muscle. In the present study, a lower n-6:n-3 PUFA ratio down-regulated the expression level of LPL in both the LM and SCAT samples, as well as aP2 in the SCAT sample, indicating that a higher proportion of n-3 PUFA could stimulate FA $\beta$-oxidation resulting in a lower synthesis of TG and nonesterified fatty acid (NEFA) levels [18]. However, the n-6:n-3 PUFA ratio only affected the expression level of aP2 in the SCAT and not the LM samples. This may have been because aP2 is an adipocyte-specific gene which is known to be a later marker of adipogenesis, whereas LPL is widely expressed in most cell types, not just functioning in adipocytes [52]. Similar studies have reported that the gene expression 
levels of LPL and aP2 were negatively correlated with concentrations of n-3 PUFA. We can thus speculate that a lower n-6:n-3 PUFA ratio could reduce the amount of FA being delivered to the muscle by decreasing the transcription of genes involved in the muscle [53]. However, these results were not consistent with the previous study where LPL and aP2 gene expression levels increased with the content of n-3 PUFA in the muscle of pigs [54]. In addition, another study has reported that the LPL expression level increased with the concentrations of $\mathrm{C} 16: 1$ and $\mathrm{C} 18: 1$, but decreased with those of $\mathrm{C} 16: 0$ and $\mathrm{C} 18: 0$ [49]. It therefore seems that the LPL expression level was associated with not only the concentrations of PUFA but also with those of MUFA and SFA. These results again indicate that the composition of dietary FA is a factor influencing the genes regulating the endogenous synthesis of FA.

HSL is an intracellular enzyme that catalyzes the hydrolysis of TG in adipose tissue and regulates the release of NEFA from lipid stores [55]. It has been reported that blood TC level increased markedly in HSLdeficient animals [16]. In the present study, compared with higher dietary n-6:n-3 PUFA ratios, a lower dietary n-6:n-3 PUFA ratio increased the expression level of HSL in the LM sample, but decreased it in the SCAT sample, suggesting that the fat in the LM required a lower n-6: n-3 PUFA ratio for lipid hydrolysis. In contrast, the fat in the SCAT, with its higher lipid content and higher capacity for lipogenesis, required a higher n-6:n-3 PUFA ratio for hydrolysis, which was possibly related to metabolic specificities of the different tissues [56]. It has also been reported that a lower dietary n-6:n-3 PUFA ratio was more effective for increasing the expression of lipoclastic genes HSL in both LM and SCAT samples [14]. In contrast, regulation of HSL may be affected by the type of n-3 PUFA, as well as by the fat depot. For example, the expression level of HSL in retroperitoneal fat was reported to decrease on supplementation with DHA or a mixture of EPA and DHA but not with EPA supplementation alone [57].

In the present study, the effects of a higher n-6:n-3 PUFA ratio on genes involved in lipid metabolism were similar to those of a lower n-6:n-3 PUFA ratio. In a similar study in rats, it has been demonstrated that PPARy expression was down-regulated by either high n-6 PUFA (soybean oil) or high n-3 PUFA (linseed oil) [58]. Studies have shown that an elevated intake of n-3 PUFA decreased tissue levels of $n-6$ PUFA, and vice versa. However, it is worth noting that diets adequate in n-3 PUFA but extremely deficient in n-6 PUFA significantly decreased the whole-body utilization of not only n-3 PUFA but also n-6 PUFA [59]. This suggests that n-3 PUFA can reduce the requirement for $n-6$ PUFA or act synergistically with n-6 PUFA. Therefore, a balanced n-6:n-3 PUFA ratio may be more important than the intake levels of n-3 PUFA for lipid synthesis and catabolism, lipid homeostasis, and thus preventing obesity and inflammation related diseases [14]. In the present study, the optimal n-6:n-3 PUFA ratios are 3:1 and 5:1, which are also close to those commonly recommended [20]. These ratios could provide sufficient PUFA to ensure adequate energy and nutrients for lipid homeostatic metabolism and high growth performance. In contrast, the gene transcriptional regulation of FA synthesis and catabolism could be more long-term and correlated with specific tissues as well as with the enrichment of tissues with n-3 and n-6 PUFA. Dietary FA may affect lipid metabolism through many potential mechanisms, such as regulating transcriptional genes, gene interactions with different signaling pathways and the activities of proteins and enzymes. [60]. Therefore, further research is need to determine the optimal n-6:n-3 PUFA ratio for growth, immunity, lipid metabolism and gene expressions and to elucidate the underlying metabolic pathways and mechanisms. 


\section{Conclusions}

The dietary n-6:n-3 PUFA ratio affects the growth performance, serum lipid and adipocytokine, tissue FA composition and expression of genes involved in the lipid metabolism of finishing pigs. Reducing the n6:n-3 PUFA ratio appropriately could help to optimize the blood lipid and adipocytokine parameters and FA composition of the tissues. The increase in the amount of n-3 PUFA deposited in the tissue induced by a lower dietary n-6:n-3 PUFA ratio was associated with the down-regulation of some genes involved in the metabolism of lipid biosynthesis. When the n-6:n-3 PUFA ratios are between 3:1 and 5:1, lipogenesis and lipolysis may be in balance, leading to a better production performance.

\section{Abbreviations}

FA: fatty acid; MUFA: monounsaturated fatty acid; PUFA: polyunsaturated fatty acids; SFA: saturated fatty acids; ALA: arachidonic acid; DHA: docosahexaenoic acid; EPA: eicosapentaenoic acid; ADG: average daily gain; ADFI: average daily feed intake; FCR: feed conversion ratio; LM: lingissimus dorsi muscle; SCAT: subcutaneous adipose tissue; TG: Triglyceride; TC: total cholesterol; HDL-C: high-density lipoprotein cholesterol; LDL-C: low-density lipoprotein cholesterol; LEP: leptin; IL-6: interleukin 6; APN: adiponectin; PPARY: peroxisome proliferator-activated receptor-ү; LPL: lipoprotein lipase; aP2: adipocyte fatty acid binding protein; HSL: hormone- sensitive lipase; NEFA: non-esterified fatty acid.

\section{Declarations}

\section{Acknowledgements}

Not applicable.

\section{Authors' contributions}

XJL and JC conceived the study. HZC and LYW performed the experiments, acquisition of data and interpretation of data. $\mathrm{XL}$ and $\mathrm{JXZ}$ conducted the experiment of fatty acid analysis and serum indexes analysis. JTL and HZC were responsible for animal feeding experiments. JC wrote the manuscript. XJL supervised the study and approved the final version. All authors read and approved the final manuscript.

\section{Funding}

This study was supported by the Key Program of Basic Scientific Research Projects of ordinary universities from Liaoning (LSNZD201703), and partly by Major Science and Technology innovation project of Liaoning Province (2019JH1/10200002) and Major Project of Liaoning Province (2020JH1/10200003). 


\section{Availability of data and materials}

The datasets used and/or analysed during the current study are available from the corresponding author on reasonable request.

\section{Ethics approval and consent to participate}

All animal care and use procedures for this study were approved by Animal Welfare Ethics Committee at Shenyang Agriculture University (No. 201906001).

\section{Consent for publication}

Not applicable

\section{Author details}

${ }^{1}$ College of Animal Science \& Veterinary Medicine, Shenyang Agricultural University, Shenyang 110866, PR China. ${ }^{2}$ Shenyang Wise Diligence Agriculture-Technology Company Limited, Xinmin 110300, PR China.

\section{Competing interest}

The authors declare that they have no competing interest.

\section{References}

1. Ratnayake WMN, Galli C. Fat and fatty acid terminology, methods of analysis and fat digestion and metabolism: a background review pa Ann Nutr Metab. 2009;55(1-3):8-43. https://doi.org/10.1159/000228994

2. Siriwardhana N, Kalupahana NS, Moustaid-Moussa N. Health benefits of $n-3$ polyunsaturated fatty acids: eicosapentaenoic acid and docosahexaenoic acid. Adv Food Nutr Res. 2012;65:211-22. https://doi.org/10.1016/B978-0-12-416003-3.00013-5

3. Simopoulos AP. Evolutionary aspects of diet, the omega-6/omega-3 ratio and genetic variation: nutritional implications for chronic diseases. Biomed Pharmacother. 2006;60(9):502-7. https://doi.org/10.1016/j.biopha.2006.07.080

4. Lluis L, Taltavull N, Munoz-Cortes M, Sanchez-Martos V, Romeu M, Giralt M, et al. Protective effect of the omega-3 polyunsaturated fatty acids: Eicosapentaenoic acid/Docosahexaenoic acid 1:1 ratio on 
cardiovascular disease risk markers in rats. Lipids Health Dis. 2013;12:140.

http://www.lipidworld.com/content/12/1/140

5. Jimenez-Colmenero F, Ventanas J, Toldra F. Nutritional composition of dry-cured ham and its role in a healthy diet. Meat Sci. 2010;84(4):585-93. https://doi.org/10.1016/j.meatsci.2009.10.029

6. Benítez R, Núñez Y, Fernández A, Isabel B, Fernández Al, Rodríguez C, et al. Effects of dietary fat saturation on fatty acid composition and gene transcription in different tissues of Iberian pigs. Meat Sci. 2015;102:59-68. https://dx.doi.org/10.1016/j.meatsci.2014.12.005

7. Mourot J, Guillevic M. Effect of introducing hemp oil into feed on the nutritional quality of pig meat. OCL. 2015;22(6):D612. https://doi.org/10.1051/ocl/2015035

8. Liu WC, Kim IH. Effects of different dietary n-6:n-3 PUFA ratios on growth performance, blood lipid profiles, fatty acid composition of pork, carcass traits and meat quality in finishing Pigs. Ann Anim Sci. 2018;18(1):143-54. https://doi.org/10.1515/aoas-2017-0026

9. Livak KJ, Schmittgen Analysis of Relative Gene Expression Data Using Real-Time Quantitative PCR and the 2- $\Delta \Delta C T$ Method. Methods. 2001;25(4):402-8. https://doi.org/10.1006/meth.2001.1262

10. Wang BK, Liu WB, Xu C, Cao XF, Zhong XQ, Shi HJ, et al. Dietary carbohydrate levels and lipid sources modulate the growth performance, dietary profiles and intermediary metabolism of blunt snout bream. Megalobrama amblycephala in an interactive pattern. Aquaculture, 2017;481:140-53. https://doi.org/10.1016/j.aquaculture.2017.08.034

11. Bertol TM, de Campos RML, Ludke JV, Terra NN, de Figueiredo EAP, Coldebella A, et al. Effects of genotype and dietary oil supplementation on performance, carcass traits, pork quality and dietary composition of backfat and intramuscular fat. Meat Sci. 2013;93(3):507-16. https://doi.org/10.1016/j.meatsci.2012.11.012

12. Kim JS, Ingale SL, Lee SH, Choi YH, Kim EH, Lee DC, et al. Impact of dietary fat sources and feeding level on adipose tissue fatty acids composition and lipid metabolism related gene expression in finisher pigs. Anim Feed Sci Tech. 2014;196:60-7. https://doi.org/10.1016/j.anifeedsci.2014.06.007

13. Duan YH, Li FN, Li LL, Fan JX, Sun XM, Yin YL. n-6:n-3 PUFA ratio is involved in regulating lipid metabolism and inflammation in pigs. Brit J Nutr. 2014;111:445-51. https://doi.org/10.1017/S0007114513002584

14. Li FN, Duan YH, Li YH, Tang YL, Geng MM, Oladele OA, et al. Effects of dietary n-6:n-3 PUFA ratio on fatty acid composition, free amino acid profile and gene expression of transporters in finishing pigs. Brit J Nutr. 2015;113(5):739-48. https://doi.org/10.1017/S0007114514004346

15. Teixeira PJ, Sardinha LB, Going SB, Lohman D Total and regional fat and serum cardiovascular disease risk factors in lean and obese children and adolescents. Obesity Res. 2001;9(8):432-42. https://doi.org/10.1038/oby.2001.57

16. Peng M, Xu W, Tan P, Du JL, Mai KS, Zhou HH, et al. Effect of dietary fatty acid composition on growth, fatty acids composition and hepatic lipid metabolism in juvenile turbot (Scophthalmus maximus L.) fed diets with required n3 LC-PUFAs. Aquaculture. 2017;479:591-600. https://dx.doi.org/10.1016/j.aquaculture.2017.06.032 
17. Tartrakoon W, Tartrakoon T, Kitsupee N. Effects of the ratio of unsaturated dietary to saturated dietary on the growth performance, carcass and meat quality of finishing pigs. Anim Nutr. 2016;2:7985. https://doi.org/10.1061/j.aninu.2016.03.004

18. Shearer GC, Savinova OV, Harris WS. Fish oil-How does it reduce plasma triglycerides? BBA-Mol Cell Biol L. 2012; 1821(5):843-851. https://doi.org/10.1016/j.bbalip.2011.10.011

19. Vodolazska $D$, Lauridsen $C$. Effects of dietary hemp seed oil to sows on fatty acid profiles, nutritional and immune status of piglets. J Anim Sci Biot. 2020;11:28. https://doi.org/10.1186/s40104-0200429-3

20. Yang LG, Song ZX, Yin H, Wang YY, Shu GF, Lu HX, et al. Low n-6/n-3 PUFA Ratio Improves Lipid Metabolism, Inflammation, Oxidative Stress and Endothelial Function in Rats Using Plant Oils as n-3 Dietary Source. Lipids. 2016;51:49-59. https://doi.org/10.1007/s11745-015-4091-z

21. Umesha SS, Naidu KA. Vegetable oil blends with alpha-linolenic acid rich garden cress oil modulate lipid metabolism in experimental rats. Food Chem. 2012;135(4):2845-51.

https://doi.org/10.1016/j.foodchem.2012.05.118

22. Drevon CA. Fatty acids and expression of adipokines. BBA-Mol Basis Dis. 2005;1740,287-92. https://doi.org/10.1016/j.bbadis.2004.11.019

23. Hun CS, Hasegawa K, Kawabata T, Kato M, Shimokawa T, Kagawa Y. Increased uncoupling protein2 mRNA in white adipose tissue, and decrease in leptin, visceral fat, blood glucose, and cholesterol in KK-Ay mice fed with eicosapentaenoic and docosahexaenoic acids in addition to linolenic acid. Biochemical and biophysical research communications. 1999;259:85-90. https://doi.org/10.1006/bbrc.1999.0733

24. Pérez-Matute P, Marti A, Martinez JA, Fernández-Otero MP, Stanhope KL, Havel PJ, et al. Eicosapentaenoic fatty acid increases leptin secretion from primary cultured rat adipocytes: role of glucose metabolism. Am J Physiol Regul Integr Comp Pgysiol. 2005;288(6):R1682-8. https://doi.org/10.1152/ajpregu.00727.2004

25. Pérez-Matute P, Pérez-Echarri N, Martínez JA, Marti A, Moreno-Aliaga MJ. Eicosapentaenoic acid actions on adiposity and insulin resistance in control and high-fat-fed rats: role of apoptosis, adiponectin and tumour necrosis factor-alpha. Brit J Nutr. 2007;97:389-98. https://doi.org/10.1017/S0007114507207627

26. Krebs JD, Browning LM, McLean NK, Rothwell JL, Mishra GD, Moore CS, et al. Additive benefits of long-chain n-3 polyunsaturated fatty acids and weight-loss in the management of cardiovascular disease risk in overweight hyperinsulinaemic women. Int J Obes. 2006;30:1535-44. https://doi.org/10.1038/sj.ijo.0803309

27. Munro IA, Garg ML. Dietary supplementation with n-3 PUFA does not promote weight loss when combined with a very-low-energy diet. Brit J Nutr. 2012;108:1466-74. https://doi.org/10.1017/S0007114511006817

28. Pérusse L, Collier G, Gagnon J, Leon AS, Rao DC, Skinner JS, et al. Acute and chronic effects of exercise on leptin levels in humans, J Appl Physiol. 1997;83:5-10. 
https://doi.org/10.1152/jappl.1997.83.1.5

29. Calder, P. C. Polyunsaturated fatty acids, inflammation and immunity. Lipids. 2001;36(9): 1007-24. https://doi.org/10.1007/s11745-001-0812-7

30. Bagga D, Wang L, Farias-Eisner R, Glaspy JA, Reddy ST. Differential effects of prostaglandin derived from omega- 6 and omega- 3 polyunsaturated fatty acids on COX-2 expression and IL- 6 secretion. Proc Natl Acad Sci USA. 2003;100:1751-6. https://doi.org/1073/pnas.0334211100

31. Lin S, Hou J, Xiang F, Zhang XL, Che LQ, Lin Y, et al. Mammary inflammation around parturition appeared to be attenuated by consumption of fish oil rich in n-3 polyunsaturated fatty acids. Lipids Health Dis. 2013;12(1):190. https://doi.org/10.1186/1476-511X-12-190

32. Rallidis L, Paschos G, Liakos GK, Velissaridou AH, Anastasiadis G, Zampelas A. Dietary alphalinolenic acid decreases C-reactive protein, serum amyloid A and interleukin- 6 in dyslipidaemic patients. Atherosclerosis. 2003;167(2),237-42. https://doi.org/10.1016/s0021-9150(02)00427-6

33. Zhang YR, Min JX, Zhang LJ. Anti-inflammatory and Immunomodulatory Effects of Marine n-3 Polyunsaturated Fatty Acids on Human Health and Diseases. J Ocean Univ China. 2019;18(2):481492. https://doi.org/10.1007/s11802-019-3620-4

34. Juhl C, Beck-Sickinger AG. Molecular tools to characterize adiponectin activity. Vitam Horm. 2012;90,31-56. https://doi.org/10.1016/b978-0-12-398313-8.00002-6

35. Lindberg S, Jensen JS, Bjerre M, Pedersen SH, Frystyk J, Flyvbjerg A, et al. Adiponectin, type 2 diabetes and cardiovascular risk. Eur J Prev. Cardiol. 2015;22(3):276-83. https://doi.org/10.1177/2047487313514894

36. Han SJ, Boyko EJ, Fujimoto WY, Kahn SE, Leonetti DL. Low plasma adiponectin concentrations predict increases in visceral adiposity and insulin resistance. J Clin Endocrinol. Metab. 2017;102(12):4626-33. https://doi.org/10.1210/jc.2017-01703

37. Burghardt PR, Kemmerer ES, Buck BJ, Osetek AJ, Yan C, Koch LG, et al. Dietary n-3:n-6 fatty acid ratios differentially influence hormonal signature in a rodent model of metabolic syndrome relative to healthy controls. Nutr Metab. 2010;7:53. https://doi.org/10.1186/1743-7075-7-53

38. Bertrand C, Pignalosa A, Wanecq E, Rancoule C, Batut A, Deleruyelle S, et al. Effects of dietary eicosapentaenoic acid (EPA) supplementation in high-fat fed mice on lipid metabolism and apelin/APJ system in skeletal muscle. PLoS One. 2013;8(11):e78874.

https://doi.org/10.1371/journal.pone.0078874

39. Gammelmark A, Madsen T, Varming K, Lundbye-Christensen S, Schmidt EB. Low-dose fish oil supplementation increases serum adiponectin without affecting inflammatory markers in overweight subjects. Nutr Res. 2012;32(1):15-23. https://doi.org/10.1016/j.nutres.2011.12.007

40. Itoh M, Suganami T, Satoh N, Tanimoto-Koyama K, Yuan X, Tanaka M, et al. Increased adiponectin secretion by highly purified eicosapentaenoic acid in rodent models of obesity and human obese subjects. Arterioscler Throm Vas Biol. 2007;27:1918-25.

https://doi.org/10.1161/ATVBAHA.106.136853 
41. Montaño A, Hernández M, Garrido I, Llerena JL, Espinosa F. Fatty acid and phenolic compound concentrations in eight different monovarietal virgin olive oils from extremadura and the relationship with oxidative stability. Int J Mol Sci. 2016;17:1960. https://doi.org/10.3390/ijms17111960

42. Hodge AM, Simpson JA, Gibson RA, Sinclair AJ, Makrides M, O'Dea K, et al. Plasma phospholipid fatty acid composition as a biomarker of habitual dietary fat intake in an ethnically diverse cohort. Nutr Metab Cardiovasc Dis.2007;17:415-26. https://doi.org/10.1016/j.numecd.2006.04.005

43. Picklo Sr, MJ, Idso J, Seeger DR, Aukema HM, Murpgy EJ. Comparative effects of high oleic acid vs high mixed saturated fatty acid obesogenic diets upon PUFA metabolism in mice. Prostag Leukotr Ess. 2017;119:25-37. https://doi.org/10.1016/j.plefa.2017.03.001

44. Juárez M, Dugan MER, Aldai N, Aalhus JL, Patience JF, Zijlstra RT, et al. Feeding co-extruded flaxseed to pigs: Effects of duration and feeding level on growth performance and backfat fatty acid composition of grower-finisher pigs. Meat Sci. 2010;84:578-84. https://doi.org/10.1016/j.meatsci.2009.10.015

45. Nakamura MT, Yudell BE, Loor JJ. Regulation of energy metabolism by long-chain fatty acids. Prog Lipid Res. 2014;53:124-44. https://doi.org/10.1016/j.plipres.2013.12.001

46. Michalik L, Auwerx J, Berger JP, Chatterjee VK, Glass CK, Gonzalez FJ, et al. International union of pharmacology. LXI. Peroxisome proliferatoractivated receptors. Pharmacol Rev. 2006;58(4):726-41. https://doi.org/10.1124/pr.58.4.5

47. Oster RT, Tishinsky JM, Yuan ZF, Robinson LE. Docosahexaenoic acid increases cellular adiponectin mRNA and secreted adiponectin protein, as well as PPARY mRNA, in 3T3-L1 adipocytes. Applied physiology, nutrition, and metabolism, Appl Physiol Nutr Me. 2010;35(6):783-9. https://doi.org/10.1139/H10-076

48. Urrutia O, Mendizabal JA, Insausti K, Soret B, Purroy A, Arana A. Effects of addition of linseed and marine algae to the diet on adipose tissue development, fatty acid profile, lipogenic gene expression, and meat quality in Lambs. PLoS One, 2016;(2). https://doi.org/10.1371/journal.pone.0156765

49. Wang W, Xue WD, Jin BQ, zhang XX, Ma F, Xu XF. Candidate gene expression affects intramuscular fat content and ftty acid compositon in pigs. J Appl Genet, 2013,54:113-8. https://doi.org/10.1007/s13353-012-0131-z

50. Furuhashi M, Hotamisligil GS. Fatty acid-binding proteins: role in metabolic diseases and potential as drug targets. Nat Rev Drug Discov. 2008;7:489-503. https://doi.org/10.1038/nrd2589

51. Esenabhalu VE, Cerimagic M, Malli R, Osibow K, Levak-Frank S, Frieden M,et al. Tissue-specific expression of human lipoprotein lipase in the vascular system affects vascular reactivity in transgenic mice. Brit J Pharmacol. 2002;135(1):143-54. https://doi.org/10.1038/sj.bjp.0704440

52. Haunerland $\mathrm{NH}$, Spener F. Fatty acid-binding proteins-insights from genetic manipulations. Prog Lipid Res, 2004;43:328-49. https://doi.org/10.1016/j.plipres.2004.05.001

53. Assumpçãoa RP, Muccia DB, Fonsecaa FCP, Marcondesa H, Sardinhaa FLC, Citellib M, et al. Fatty acid profile of maternal and fetal erythrocytes and placental expression of fatty acid transport 
proteins in normal and intrauterine growth restriction pregnancies. Prostag Leukotr Ess. 2017;125:2431. https://doi.org/10.1016/j.plefa.2017.08.011

54. Luo HF, Wei HK, Huang FR, Zhou Z, Jiang SW, Peng J. The effect of linseed on intramuscular fat content and adipogenesis related genes in skeletal muscle of pigs. Lipids. 2009;44(11):999-1010. https://doi.org/10.1007/s11745-009-3346-y

55. Enevoldsen, LH, Stallknecht B, Langfort J, Petersen LN, Holm C, Ploug T, et al. The effect of exercise training on hormone-sensitive lipase in rat intra-abdominal adipose tissue and muscle. J Physiol. 2001;536:871-7. https://doi.org/10.1111/j.1469-7793.2001.t01-1-00871.x

56. Hocquette JF, Gondret F, Baéza E, Médale F, Jurie C, Pethick DW. Intramuscular fat content in meatproducing animals: development, genetic and nutritional control, and identification of putative markers. Animal. 2010; 4(2): 303-19. https://doi.org/10.1017/S1751731109991091

57. Albracht-Schulte K, Kalupahana NS, Ramalingam L, Wang S, Rahman SM, Robert-McComb N, et al. Omega-3 fatty acids in obesity and metabolic syndrome: a mechanistic update. J Nutr Biochem. 2018;58:1-16. https://doi.org/10.1016/j.jnutbio.2018.02.012

58. Escobar ELO, Gomes-Marcondes MCC, Carvalho HF, Dietary fatty acid quality affects AR and PPARY levels and prostate growth. Prostate. 2009;69(5):548-58. https://doi.org/10.1002/pros.20905

59. Bazinet RP, Douglas H, Cunnane SC. Whole-body utilization of n-3 PUFA in n-6 PUFA-deficient rats. Lipids. 2003;38(2):187-9. https://doi.org/1007/s11745-003-1050-8

60. Albert BB, Derraik JG, Brennan CM, Biggs JB, Garg ML, Cameron-Smith D, et al. Supplementation with a blend of krill and salmon oil is associated with increased metabolic risk in overweight men. Am J Clin Nutr. 2015;102(1):49-57. https://doi.org/10.3945/ajcn.114.103028 